\title{
Digital Divide: The Case of Developing Countries
}

\author{
Michelle W. L. Fong \\ Victoria University, Melbourne, Australia \\ Michelle.Fong@vu.edu.au
}

\begin{abstract}
This research paper assesses the impact of ICTs (which includes the Internet, mobile phone, pager, personal computer, and telephone) on Gross National Income (GNI) per capita in developing countries in 2005 . It found a significant relationship between GNI per capita (in PPP international dollar) and adoption of each ICT (mobile phone, personal computer, and te lephone) but not for Internet technology adoption. In addition, it identifies factors that developing countries need to consider in the adoption and application of ICTs for economic development.
\end{abstract}

Keywords: Economic growth, economic development, Internet, mobile phone, personal computer, telephone, and challenges.

\section{Introduction}

When information technology became popular in applications (for automation) in the 1970s, discussions and debates on the impact of this technology were centered on 'information gaps' between developed and developing countries under the concern that world populations may soon be divided into groups of inequality - 'information elite' and 'information ignorant'. However, rapid developments in ICTs (information and communication technologies) soon highlighted the greater complexities associated with this technological disparity. It came to light that technological disparity can occur within a single developed country, rather than between developed and developing countries. In addition, this disparity is not necessarily confined to computer or Internet use but may involve accessibility to other forms of ICT such as fixed line telephone, mobile phone, and pager. As a result, this awareness gave birth to another term, the 'digital divide', which encompasses a broader and more cavernous meaning than 'information gap'. 'Digital divide' began to gain popularity when it became a mainstream political topic in the US in the 1990s, and eventually, it achieved recognition as an English colloquial term in dictionaries such as 'The Australian Concise Oxford Dictionary $4^{\text {th }}$ edition' and 'The Penguin English Dictionary $2^{\text {nd }}$ edition'. Although the term 'digital divide' has taken on a broader and more cavernous meaning than 'information gap', there have been times that the latter was used synonymously with the former.

Material published as part of this publication, either on-line or in print, is copyrighted by the Informing Science Institute. Permission to make digital or paper copy of part or all of these works for personal or classroom use is granted without fee provided that the copies are not made or distributed for profit or commercial advantage AND that copies 1) bear this notice in full and 2) give the full citation on the first page. It is permissible to abstract these works so long as cred it is given. To copy in all other cases or to republish or to post on a server or to redistribute to lists requires specific permission and payment of a fee. Contact Publisher@InformingScience.org to request redistribution permission.
ICT is not a panacea for all the problems of developing countries. However, digital divide has important implications for these countries as the uneven distribution of ICTs access may mean that segments or groups who have no or limited accessibility to these technologies may be denied of socioeconomic opportunities such as: 
- Social equality. ICTs have the potential to dispel disadvantages that may be associated with cultural barriers. For example, ICTs may be used to improve gender equality in education. Through ICTs, girls may undertake their education through e-learning at home in a society where cultural barriers isolate girls. In addition, they may be empowered to utilize high-end technology in the ir economic participation in later years. (Daly, 2003, K. Chen, 2004).

- Social mobility which refers to the upward movement in status of individuals or groups based on wealth, occupation, education, or some other social variable in a society where one status is not dictated or decreed by birth of origin. Advancements in ICTs are capable of bestowing advantages in education, job-training, health-care as well as social networking and quality of life that they could make a difference between upward social mobility and a declining standard of living. In other words, ICTs could improve life for those who are within reach of these technologies.

- Economic equality. Bridging the digital divide has implications in terms of fostering economic equality, educational potential, and earning potential.

- e-democracy. ICTs can be a powerful tool for increasing transparency and facilitating information and communication processes among stakeholders. ICTs may lead to increased democratization by enabling citizens or constituents to participate in the decisionmaking process of policymakers and government through the electronic channel. However, e-democracy has yet to reach its ideal level of actualization in the political participation process.

- Economic Growth and Innovations. Long-term economic growth has often been associated with technological progress.

\section{Literature Review}

There were past studies that confirmed the positive relationship between ICT and economic growth (Bongo, 2005). These studies suggest that ICTs have the potential in alleviating poverty in poor countries. These technologies have also been viewed by governments and international aid agencies as important tools for national integration because they are capable of enabling greater access to health and education services, and creating economic opportunities for underprivileged population groups (Jensen, 2007; Mercer, 2001; Oberski, 2004; Reisman, Roger, \& Edge, 2001; Un ited Nations Develop ment Programme [UNDP], 2001; The World Bank, 2001). In fact, the '2006 Information and Communications for Development' report published by The World Bank (2006) considered ICTs to be crucial to poverty reduction. Jensen's (2007) microlevel study on fishermen in Kerala shows that the adoption of mobile phone can promote economic and social welfare not only for these fishermen but also for consumers. This study implies that poverty alleviation in one sector can have positive spillover effect for other individuals in the supply value chain or other sectors within the economy. There were also other reported cases in which wireless communications technologies were observed to have generated benefits for communities. For example, villages in Robib, Cambodia, were reported to have leapfrogged from an agricultural to an information economy through wireless network (oneworld radio, 2006). The villagers were able to access medical and health services, and global marketplace for their cottage industry through wire less communications technology. In Africa, it was found that information available through the use of mobile phone enabled farmers in Senegal to double the prices of their crops and herders in Angola to locate their cattle through GPS (global positioning system) technology (oneworld radio, 2006). If such benefits can be harnessed from strategic applications of ICTs in each economic sector, it may be translated into economic growth or sus- 
tainability, and welfare gains at the national aggregate level (Organisation for Economic Cooperation and Development [OECD], 2005).

Developing countries are generally latecomers to the ICT revolution. If these countries emulate the adoption of ICTs, which are also being adopted in industrialized countries, they would be exposed to the same technological potentials as the developed countries would. Successful exploitation of the technological potentials by developing countries has significant implication on the narrowing of economic gap between developed and developing countries as the latter catches up in economic development. EIU's study (2004) highlighted a crucial point for harnessing positive effect from ICTs application for developing countries. It examines the relationship between ICTs and economic growth in 26 developed countries and 34 less-developed countries between 1995 and 2002, and reported strong evidence of positive association between ICTs and economic growth for developed countries but not for developing countries. This study attributed the weak association, in the latter group of countries, to the absence of a critical mass in ICT adoption, suggesting that significant economic growth will only be attained if a minimum threshold of ICT penetration and usage is achieved. In other words, if there is a digital divide between developed and developing countries, it is likely to result in considerable differences in economic development.

Investment in ICTs and effective applications of these technologies for economic growth are like ly not to be straightforward for developing countries. One of the major challenges confronting developing countries has been that investments in ICT compete with the provis ion of basic necessities for the poor (Ochieng, 2000). Investment in ICTs and their enabling infrastructures constitute an expensive affair for developing countries, which tends to bear a high burden of debts (Y. Chen, Farinelli, \& Johansson, 2004). In addition, such investment will involve a long pay-back period because of the nascent demand conditions in their market, which usually are weak or inadequate.

\section{The Research Paper}

This research paper assesses the impact of ICTs (which includes the Internet, mobile phone, personal computer, and telephone) on Gross National Income (GNI) per capita in developing countries in 2005. In addition, it identifies factors that developing countries need to consider in the adoption and application of ICTs for economic development.

\section{Variables and Methodology}

This paper used the regression method to investigate the relationship between Gross National Income per capita (in PPP international dollar) and each type of ICT access (as represented by the respective ICT penetration index) in 91 lower-middle-income and low-income developing countries in 2005. A positive significant coefficient from the regression model will suggest a narrowing of income gap for the developing countries with richer developed countries through an in-

crease in income. The GNI per capita is measured in Purchasing Power Parity (PPP) international dollar. The use of PPP allows GNI per capita to be compared among nations without distortions from relative cost of living and inflation rates of different countries. The average GNI per capita in PPP international dollar for developing countries in the sample is 2704.51. The distribution of the data is normal, without significant skewness and kurtosis. The dependent and independent variables are as follows:

Dependent variable:

GNI per capita (in PPP international dollar)

Independent variables:

Internet $=$ Internet user index; 
Mobile $=$ Mobile phone index;

$\mathrm{PC}=$ Personal computer index; and

Telephone $=$ Telephone index.

\section{Results and Discussion}

The results in Table 1 show that the adoption rates of telephone, personal computer, and mobile phone have significant relationship with GNI per capita (in PPP international dollar) in lowermiddle-income and low-income developing countries in 2005. The adoption rate of Internet, however, did not have significant relationship with the dependent variable and this may be due to the absence of a critical mass in Internet connection in these countries to suffic iently harness this technology's potential for economic development.

Table 1 - Pearson's corre lation coefficients

\begin{tabular}{|l|c|}
\hline Variables: & Coefficients: \\
\hline Internet & 5.858 \\
\hline Mobile & $75.881 * * *$ \\
\hline PC & $109.772 * *$ \\
\hline Telephone & $171.149 * * *$ \\
\hline & Note: *** indicates significance at 1\%; $* *$ indicates significance at 5\%; \\
$*$ indicates significance at $10 \%$.
\end{tabular}

The results in Table 1 show that a percentage increase in a mobile phone index is associated with an increase of GNI per capita of 75.881 international dollars for these economies. In addition, an increase of personal computer index by one percentage is associated with an increase of GNI per capita by 109.772 international dollars during the same period. An increase of a percentage in telephone index is related to an increase of 171.149 in GNP per capita in international dollars. A number of developing countries have used mobile telephony as technology springboard for getting into the mainstream of communications because it is capable of providing a quicker and less costly solution than the fixed-line infrastructure (Fong, 2009). Instead of spending vast amount of resources and time to establish fixed-line network to facilitate telecommunications, these countries can substitute this infrastructure with cellular towers, which are relatively cheap and easy to develop. However, the regression results show that fixed-line infrastructure is associated with highest income as compared to mobile phone and personal computer. Nevertheless, the significant results for telephone, mobile phone, and personal computer seem encouraging. This study suggests that an increase in the adoption of mobile phone, personal computer, and fixed-line telephone by one percent will bring about an increase in average income per person in lower-middleincome and low-income developing countries by approximately $2.8 \%, 4.1 \%$, and $6.3 \%$ respectively. Other studies which embrace a wider dimension in time period, variables and countries in statistical analyses have found a positive relationship between economic growth and ICTs. In this paper, the use of GNI per capita in this regression model reflects the changes in average income of an individual and assists in understanding how standard of living may improve under each type of ICT.

\section{Factors Relevant to ICTs Adoption and Applications}

For effective applications of ICTs for economic development, there are factors which developing countries need to take into consideration for the mastery, applications and diffusion of these tech- 
nologies. Table 2 shows factors that are relevant to the adoption and application of ICTs in developing economies:

Table 2: Factors relevant to the mastery, applications and diffusion of ICTs in developing countries.

\begin{tabular}{|c|c|}
\hline Factors & Example of issues \\
\hline $\begin{array}{l}\text { Market condition: } \\
\text { - Market demand } \\
\text { - Market competition }\end{array}$ & $\begin{array}{l}\text { - Market competition for rational pricing of ICT \& } \\
\text { access, } \\
\text { - Develop locally relevant content and languages to } \\
\text { promote advanced technology uptake, } \\
\text { - Foreign participation through investment to break- } \\
\text { down monopoly structure. }\end{array}$ \\
\hline Institutional capacity & $\begin{array}{l}\text { - Support intellectual capital development, } \\
\text { - Develop stable learning and attractive investment } \\
\text { environment, } \\
\text { - Ensuring security and stability in the environment, } \\
\text { - Establish an enabling regulatory and legislative } \\
\text { framework, } \\
\text { - Economic, social, and political stability. }\end{array}$ \\
\hline Socia1/Economic & $\begin{array}{l}\text { - Ensure equity in digital access, } \\
\text { - Ensure affordability of ICTs access, } \\
\text { - Narrow or erase digital divide. }\end{array}$ \\
\hline Human capabilities & $\begin{array}{l}\text { - Improve literacy and computer literacy rate, } \\
\text { - Nurture requisite skills and expertise. } \\
\text { - Continuous investment. }\end{array}$ \\
\hline Government & $\begin{array}{l}\text { - Definitive guiding policies, } \\
\text { - Strategic deployment of ICT, } \\
\text { - Initiate coordination and linkages among actors in } \\
\text { the system. }\end{array}$ \\
\hline Stakeholders & $\begin{array}{l}\text { - Interaction and strategic link among actors in the } \\
\text { system, } \\
\text { - Regional and international cooperation and collabo- } \\
\text { ration, } \\
\text { - Identify e-champions and e-leaders to spearhead } \\
\text { ICTs investment projects. }\end{array}$ \\
\hline Utility infrastructure & - Electricity, transportation networks, etc. \\
\hline
\end{tabular}


In Table 2, there are certain conditions such as literacy and education that cannot be immediately achieved. The nurturing of human capabilities requires substantial investment in education and skills transfer, and also government intervention to expedite the development and accumulation of human capabilities. The government, besides being a provider of national education, can use incentives to encourage private initiatives in the provision of training resources.

In regard to market condition, telecommunication markets in developing economies tend to be operated by monopoly and charge high access fees which are serious obstacle to advanced technology uptake and investment. It has been observed by ITU (2004) that mobile markets of competitive structure have significantly higher rates of mobile penetration than monopoly markets, even where per-capita incomes are the same. Competition is important for making access cost affordable to users, and developing products and services that meet users' requirements. This in turn would help to generate substantive market demand and confidence in further technology investment.

In addition to achieving competitive market condition, strong legis lative frameworks must be introduced for environmental stability and security, to the extent that businesses are confident to invest and consumers are confident to uptake these ICTs. Government in developing countries is likely to face the challenge of designing appropriate regulatory environment to support and enable effective operation of sophisticated telecommunication infrastructure. However, appropriate regulatory environment could be achieved through goodwill assistance from experienced international aids agencies and developed countries. Such assistance should not be limited to regulatory or legis lative environment, developing countries in fact requires partnerships and long-term support at the local, national and international levels for their capabilities and other institutional capacity building, research and development, and innovation of leapfrog technologies.

Technology by itse If does not solve problems, but the availability and use of ICTs as well as associated infrastructures (such as electricity and transportation) are a pre-requisite for economic and social development in developing countries. It must also be noted that constraint in resources may result in skewed investment policies favouring urban regions, and this may be culpable of creating a digital divide within the ir own economies. In regard to preventing the occurrence of digital divide, government-donor-community-enterpr ise partnership may be initiated to support ongoing projects of expanding ICTs access to rural areas. In addition, commitments from a strong network of governmental and non-government participants including e-leaders and echampions, are vital for its success.

\section{Conclusion}

The regression analysis in this paper shows there is a significant relationship between GNI per capita (in PPP international dollars) and adoption of each ICT (mobile phone, personal computer, and telephone) with the exception of Internet technology. This study suggests that an increase in the adoption of mobile phone, personal computer, and fixed-line telephone by one percent will bring about an increase in average income per person in lower-middle-income and low-income developing countries by approximately $2.8 \%, 4.1 \%$, and $6.3 \%$ respectively. The absence of a significant relationship for Internet technology may be the result of an absence of a critical mass in Internet adoption and usage. This warrants further investigation with a more robust analytical model.

Developing countries face challenges when harnessing ICTs potential for economic development. Many of these countries have been pledged with resources shortage and constraint that they opted for wireless technologies instead of traditional fixed-line solution as a quicker and less costly way of building a telecommunication infrastructure in an attempt to catch up in economic development with more developed countries. However, economic development benefits would not be 
quickly accrued to developing countries in such a move. These countries are likely to take a considerable period of time in building their capabilities to absorb, master, use, and innovate new technologies. Nevertheless, this process may be expedited by the deliberate polic ies and guidance from government in these countries, with support from the international arena. At the same time, government in these countries must constantly reassess the impact of polic ies and align them with the social objectives so as to remain user-focused in the need to harness the technology quickly.

\section{References}

Bongo, P. (2005). The impact of ICT on economic growth. Retrieved November 30, 2007, from http://129.3.20.41/eps/dev/papers/0501/0501008.pdf

Chen, K. (2004, April 26). Xiaolingtong's existence and development. Retrieved August 14, 2006, from http://www.cttl.cn/tegd/shchgch/t20060709 394514.htm

Chen, Y., Farinelli, U., \& Johansson, T. B. (2004). Technological leapfrogging - A strategic pathway to modernization of the Chinese iron and steel industry. Energy for Sustainable Development, June, $\operatorname{VIII}(2), 18-26$.

Daly, J. A. (2003, July 9). ICT, gender equality and empowering women. Accessed November 1, 2006, http://old.developmentgateway.org/node/133831/sdm/blob?pid=5233

Economist Intelligence Unit. (2004). Reaping the benefits of ICT. Europe's productivity challenge. Report sponsored by Microsoft Euromonitor International, GMI Database. Retrieved November 12, 2008, fro $\mathrm{m}$ http://graphics.eiu.com/files/ad pdfs/MICROSOFT FINAL.pdf

Fong, M. (2009). Technology leapfrogging for developing countries. In M. Khosrow-Pour (Ed.), Encyclopedia of Information Science and Technology ( $2^{\text {nd }}$ ed.). Hershey, Pennsylvania: IGI Gobal, 3707-3713.

International Teleco mmun ication Un ion. (2004). Africa: The world's fastest growing mobile market. Does mobile technology hold the key to widening access to ICTs in Africa? Retrieved December 22, 2006 fro $\mathrm{mhttp://www.itu.int/newsarchive/press} \mathrm{releases/2004/04.html}$

Jensen, R. (2007). The dig ital provide: Information (technology) market performance, and welfare in the south Indian fisheries sector. The Quarterly Journal of Economics, CXXII(3), 879-924.

Mercer, K. (2001). Examin ing the impact of health information networks on health system integration in Canada. Leadership in Health Services, 14(3), 1-30.

Oberski, I. (2004). University continuing education: The role of commun ications and information technology. Journal of European Industrial Training, 28(5), 414-428.

Ochieng, R. O. (2000). Global information flows. Library Management Journal, 21(4), 215-216.

oneworld radio. (2006, December 18). How radio, cell phones, wireless web are empowering developing nations. Retrieved December 18, 2006 from $\mathrm{http}: / /$ radio.oneworld.net/article/view/78640/1/

Organisation for Econo mic Co-operation and Development. (2005). Good practice paper on ICTs economic growth and poverty reduction. Retrieved December 27, 2006, from http://www.oecd.org/dataoecd/2/46/35284979.pdf

Re isman, S., Roger, G. \& Edge, D. (2001). Evolution of Web-based distance learning strategies. International Journal of Educational Management, 15(5), 245-251.

The World Bank (2001). World development report. Oxford: Oxford University Press.

The World Bank. (2006). 2006 Information and Communications for Development: Global Trends and Policies. Washington DC: The World Bank.

United Nations Development Programme. (2001). Human development report. New York, NY: Oxford University Press. 


\section{Biography}

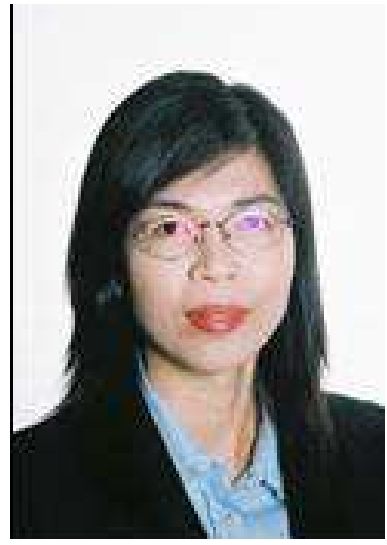

Dr. Michelle W. L. Fong is a senior lecturer in the School of Economics and Finance, Victoria University. Her research interest includes information technology systems and business systems. 